\title{
Noninvasive and nondestructive sampling for avian microsatellite genotyping: a case study on the vulnerable Chinese Egret (Egretta eulophotes)
}

Yufei Dai, Qingxian Lin, Wenzhen Fang, Xiaoping Zhou* and Xiaolin Chen*

\begin{abstract}
Background: Noninvasive and nondestructive DNA sampling techniques are becoming more important in genetic studies because they can provide genetic material from wild animals with less or even without disturbance, which is particularly useful for the study of endangered species, i.e., birds. However, nondestructively and noninvasively sampled DNA may, in some cases, be inadequate in the amount and quality of the material collected, which can lead to low amplification success rates and high genotyping errors.

Methods: In this study, noninvasive (eggshell swab, shed feather and feces), nondestructive (plucked feather and buccal swab) and invasive (blood) DNA samples were collected from the vulnerable Chinese Egret (Egretta eulophotes). DNA concentrations, PCR amplification success and microsatellite genotyping errors of different sample types were evaluated and compared to determine whether noninvasive and nondestructive samples performed as well as invasive samples in our experimental procedures.

Results: A total of 159 samples were collected in the field. Among the different sample types, the highest DNA concentrations (154.0-385.5 ng/ $\mu \mathrm{L}$ ) were obtained from blood. Those extracted from fecal samples were the lowest, ranging from 1.25 to $27.5 \mathrm{ng} / \mu \mathrm{L}$. Almost all of the DNA samples, i.e., $95.59 \%$, were successfully amplified for mtDNA ( $n=152$ ) and $92.76 \%$ of mtDNA samples were successfully genotyped for at least five of the nine microsatellite loci tested $(n=141)$. Blood samples and buccal swabs produced reliable genotypes with no genotyping errors, but in feces, allelic dropouts and false alleles occurred in all nine loci, with error rates ranging from 6.67 to $38.10 \%$ for the dropouts and from 6.06 to $15.15 \%$ for the false alleles.
\end{abstract}

Conclusions: These results indicate that both nondestructive and noninvasive samplings are suitable for avian microsatellite genotyping, save for fecal DNA. However, we should remain cautious of the appearance of genotyping errors, especially when using noninvasive material.

Keywords: Genotyping, Noninvasive sampling, Nondestructive sampling, Microsatellite, PCR, Avian genetics, Chinese Egret

\section{Background}

Over the last few decades, noninvasive and nondestructive methods of DNA sampling methods for avian studies have used eggshell swabbing or eggshell grinding

*Correspondence: xpzhou@xmu.edu.cn; xlchen@xmu.edu.cn Present Address: Key Laboratory of the Ministry of Education for Coast and Wetland Ecosystems, School of Life Sciences, College of the Environment and Ecology, Xiamen University, Xiamen 361102, China
(Schmaltz et al. 2006; Egloff et al. 2009; Martín-Gálvez et al. 2011), shed feathers (Horvâth et al. 2005; Gebhardt and Waits 2008; Isabel and Del Lama 2009; Yannic et al. 2011; Johansson et al. 2012), feces (Idaghdour et al. 2003; Baumgardt et al. 2013), buccal swabbing (Brooks et al. 2003; Bush et al. 2005; Handel et al. 2006; Yannic et al. 2011; Wellbrock et al. 2012) and feather plucking (Taberlet and Bouvet 1991; Sacchi et al. 2004; Costantini et al. 
2008; Yannic et al. 2011; Johansson et al. 2012). Noninvasive sampling can provide genetic material from wild animals without capture and nondestructive sampling is less harmful to the animals (Taberlet et al. 1999). Moreover, eggshell swabbing and collecting shed feathers and feces provides an opportunity to obtain genetic material from adult birds that are hard to capture. However, DNA obtained from nondestructive and noninvasive samples might only consist of a small amounts of material of minimalquality, containing polymerase chain reaction (PCR) inhibitors, which can lead to low amplification success rates and high genotyping errors such as allelic dropouts (ADO) and false alleles (FA) (Taberlet et al. 1996, 1999; Bonin et al. 2004; Pompanon et al. 2005; Regnaut et al. 2006).

The Chinese Egret (Egretta eulophotes) is a vulnerable migratory water bird, breeding colonially on uninhabited offshore islands (Litvinenko and Shibaev 2000; Kang et al. 2013; Birdlife international 2014). In recent years, many studies have focused on the conservation genetics and molecular ecology of this egret species. These include evaluation of genetic diversity and population structure (Zhou et al. 2010), complete mitochondrial genome (Zhou et al. 2014), polymorphism and selection of major complex histocompatibility (MHC) genes (Wang et al. 2013), species identification (Huang et al. 2012a, 2013), sex identification (Wang et al. 2011; Huang et al. 2012b), isolation of polymorphic microsatellite loci (Huang et al. 2010; Dai et al. 2013) and primer pairs for amplifying the complete mitochondrial DNA (Zhou et al. 2008). However, many evolutionary and ecological questions regarding mating systems and kinship in this egret species remain unclear because of the lack of available genetic information. In order to obtain DNA samples from every individual of a given family, especially from adults, presents a barrier to future research. Capturing adults to take blood samples may affect their incubation or lead them to abandon their nests, eggs and nestlings during the breeding season, giving rise to low reproductive success rates (Criscuolo 2001; Brown and Brown 2009). Therefore, substituting such destructive sampling techniques with noninvasive and nondestructive sampling provides an efficient solution to this problem.

In our study, we collected DNA samples from the Chinese Egret (Egretta eulophotes) by noninvasive sampling (eggshell swabs, shed feathers and feces) and nondestructive sampling (plucked feathers and buccal swabs) and compared their DNA quality, performance in PCR amplification success and microsatellite genotyping with those of invasive sampling (blood). The main objective of this study was to investigate whether noninvasive and nondestructive sampling can replace invasive sampling in avian microsatellite genotyping.

\section{Methods}

\section{Study area and sample collection}

Samples of the Chinese Egret (Egretta eulophotes) were collected at Xiaocaiyu Islet $\left(23.47^{\circ} \mathrm{N}, 117.43^{\circ} \mathrm{E}\right)$ in Fujian Province, China. The breeding colonies were visited approximately every 5 days during the breeding season from early May to late July, 2011. Fieldwork in the breeding colony was conducted in the morning and restricted to a maximum of $2 \mathrm{~h}$ per day. The nests were marked with tags, eggs were numbered with indelible ink and nestlings were correspondingly ringed with a colored leg band. To sample egg swabs the external surface of each egg, when first found, was gently handled and rubbed with a single sterile swab moistened with sterile phosphate-buffered saline (PBS; $0.2 \mathrm{M} ; \mathrm{pH}=7.2$ ); the cotton end of the swab was then cut off and kept in a $1.5 \mathrm{~mL}$ centrifuge tube with $600 \mu \mathrm{L}$ of a sterile PBS buffer $(0.2 \mathrm{M} ; \mathrm{pH}=7.2)$ for no longer than $6 \mathrm{~h}$. Buccal swabs were individually collected from about 5 day old nestlings using sterile cotton swabs, mantle feathers were plucked from the back of old nestlings, about 10 days old and kept individually in $95 \%$ ethanol. Additionally, $80 \mu \mathrm{L}$ of blood was collected from each randomly sampled 15 day old nestling by puncturing its wing vein and immediately stored in $50 \mathrm{mM}$ EDTA. Furthermore, during field surveys, naturally shed feathers with big calami $(>2 \mathrm{~cm})$ were collected near the nests and each was placed in a paper envelope. Single fecal pellets were collected from under the nests and stored individually in $95 \%$ ethanol. All of the samples were stored at $-70{ }^{\circ} \mathrm{C}$ until DNA extraction.

\section{DNA extraction}

Total genomic DNA was isolated from the nondestructive and noninvasive samples by the following method. First, samples were incubated overnight at $55{ }^{\circ} \mathrm{C}$ in $600 \mu \mathrm{L}$ of a lysis buffer $(50 \mathrm{mM}$ Tris- $\mathrm{HCl}, 50 \mathrm{mM}$ EDTA, $0.1 \mathrm{mg}$ Protease $\mathrm{K}$ and $1 \%$ sodium dodecyl sulphate). Phenolchloroform-isoamylol $(25: 24: 1)$ was added for protein precipitation. The mixture was vortexed at low speed until thoroughly homogenized, after centrifugation at $10,000 \times g$ for $10 \mathrm{~min}$ and the supernatant was transferred to a new 2-mL tube. Phenol-chloroform-isoamylol was then used for the second extraction. This extraction was purified with an Axyprep ${ }^{\text {TM }}$ DNA Gel Extraction Kit (Axygen) following the protocol from the manufacturer. Finally, a 60 $\mu \mathrm{L}$ elution buffer (2.5 mM Tris- $\mathrm{HCl}, \mathrm{pH} 7.0-8.5$, Axygen) was used to preserve the DNA, of which the concentration was quantified for all samples using a UV-visible spectrophotometer (Thermo Fisher Scientific, USA).

\section{PCR amplifications}

In order to test for PCR success rates, DNA samples were amplified for species identification using 
E. eulophotes-specific ND6 and tRNA ${ }^{\text {Glu }}$ gene primers (Huang et al. 2012a), which respectively amplified 101 and 278 bp fragments of the mitochondrial DNA (mtDNA) control region. PCR amplifications were performed in $20 \mu \mathrm{L}$ reactions containing $10 \mu \mathrm{L}$ Premix Taq (Takara), $0.4 \mu \mathrm{M}$ of each primer and $50 \mathrm{ng}$ of genomic DNA. The PCR procedure included an initial denaturation at $94{ }^{\circ} \mathrm{C}$ for $3 \mathrm{~min}$, followed by 32 cycles of $30 \mathrm{~s}$ at $94{ }^{\circ} \mathrm{C}, 40 \mathrm{~s}$ at $55^{\circ} \mathrm{C}, 40 \mathrm{~s}$ at $72{ }^{\circ} \mathrm{C}$ and a final extension of $5 \mathrm{~min}$ at $72{ }^{\circ} \mathrm{C}$. The PCR products were visualized on $1.5 \%$ agarose gels and only DNA samples successfully amplified by mtDNA were used in the amplification of nuclear DNA (nDNA).

The samples which succeeded in species identification were then amplified for sex identification using Ardeidaespecific chromo-helicase-DNA-binding protein (CHD) gene primers (Wang et al. 2011), producing two bands (140 and $250 \mathrm{bp}$ ) for females and only one 250-bp band for males. Amplification was carried out in a $20-\mu \mathrm{L}$ mix containing $10 \mu \mathrm{L}$ Premix Taq (Takara), $0.4 \mu \mathrm{M}$ of each primer and $50 \mathrm{ng}$ of genomic DNA. The PCR conditions were as follows: initial denaturation at $94{ }^{\circ} \mathrm{C}$ for $3 \mathrm{~min}$, followed by 35 cycles of $94{ }^{\circ} \mathrm{C}$ for $30 \mathrm{~s}, 48{ }^{\circ} \mathrm{C}$ for $45 \mathrm{~s}$, $72{ }^{\circ} \mathrm{C}$ for $45 \mathrm{~s}$ and a final extension at $72{ }^{\circ} \mathrm{C}$ for $5 \mathrm{~min}$. The PCR products were visualized on $2 \%$ agarose gels and stained with ethidium bromide. To increase the accuracy of the measurements, sex determination was performed for each sample at least twice and the sex was confirmed only when the results were identical. Eggshell swab samples representing maternal DNA should identify as female, while different types of samples from a single individual should be of the same sex.

To evaluate microsatellite genotyping performances, nine polymorphic microsatellite markers (Huang et al. 2010) were allocated to three multiplex PCR panels using the software MPprimer (Shen et al. 2010), based on size limitations and primer annealing temperatures (Fig. 1). To reduce the occurrence of stutter bands and ambiguity in scoring allele size, only tetranucleotide and pentanucleotide microsatellite loci were used. The $5^{\prime}$ end of the forward primer for each locus was labeled with a HEX, TAMRA or FAM fluorescent dye. The multiplex PCR panels were performed using Multiplex PCR Assay Kits (Takara) in a $20-\mu \mathrm{L}$ reaction volume containing 10 $\mu \mathrm{L}$ of Multiplex PCR Mix 2, a standard diluted primer mix, $0.1 \mu \mathrm{L}$ Multiplex PCR Mix 1 and $50 \mathrm{ng}$ of template DNA. The PCR conditions were as follows: denaturation at $95^{\circ} \mathrm{C}$ for $3 \mathrm{~min}$, followed by 35 cycles of $94^{\circ} \mathrm{C}$ for $30 \mathrm{~s}$, annealing temperature for $90 \mathrm{~s}$, extension at $72{ }^{\circ} \mathrm{C}$ for $60 \mathrm{~s}$ and a final extension for $30 \mathrm{~min}$ at $60{ }^{\circ} \mathrm{C}$. The PCR products were run on an ABI PRISM 3730 automated DNA sequencer with a LIZ500 internal size standard (Applied Biosystems) where the alleles were scored with

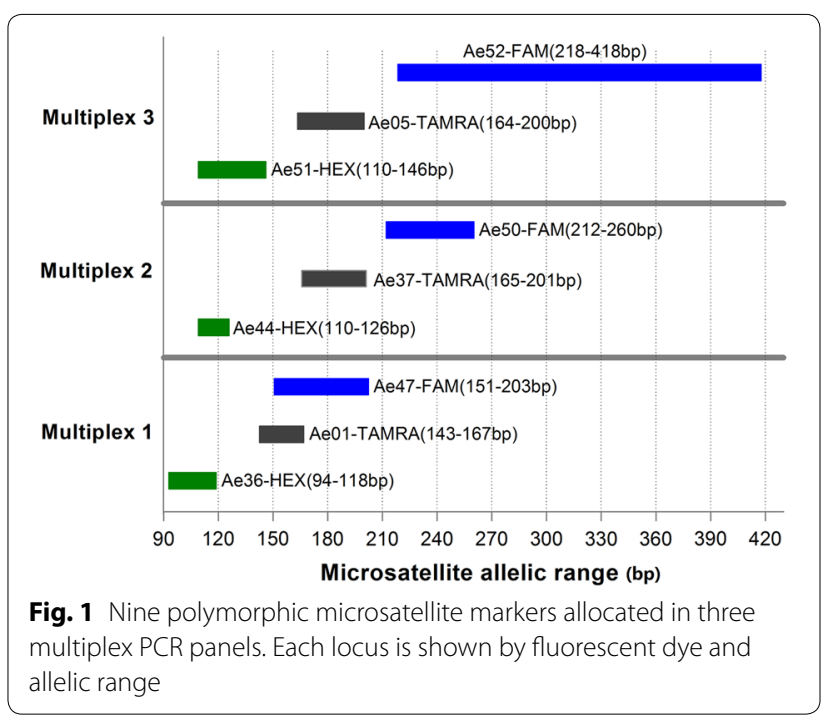

the Genemapper v4.1 (Applied Biosystems). Negative controls containing no DNA template were included in each PCR.

\section{Genetic analysis}

To obtain reliable polymorphic information on each microsatellite locus, only DNA extracted from blood samples $(n=16)$ was used. The software Cervus v3.0 (Kalinowski et al. 2007) was used to estimate expected and observed heterozygosity $\left(H_{0}\right.$ and $\left.H_{\mathrm{e}}\right)$, the number of alleles per locus $\left(N_{\mathrm{A}}\right)$ and the amount of information on polymorphism (PIC). Genepop v4.0.7 (Rousset 2008) was used to determine departures from the Hardy-Weinberg equilibrium (HWE) and linkage disequilibrium (LD) among all pairs of loci. The possible presence of stuttering, null alleles and large allele dropout was evaluated in Micro-checker v2.2.3 (Van Oosterhout et al. 2004). The genotyping performances obtained using different types of samples were evaluated by a multiple-tube approach (Taberlet et al. 1996) with the following modifications. First, DNA samples successfully amplified by mtDNA were typed for nine microsatellite loci: if less than five amplifiable loci were present, the samples were discarded from the subsequent analysis. Second, at least two additional independent PCR replicates were performed using the samples that passed the genotype screening on the first round. Finally, genotypes for each sample and locus were verified by identical alleles in three successful PCRs. Genotypes were checked for estimates of error rates (ADO and FA) by comparing the observed allele sizes with those expected sizes based on an original article by Huang et al. (2010) and by comparing the genotypes obtained in three PCRs. For the calculation of ADO and FA, equations described in Broquet and Petit (2004) and 
Pompanon et al. (2005) were employed, in which ADO should only be estimated considering heterozygous genotypes. A conservative criterion was adopted, in which a heterozygote was confirmed by the results of two double alleles and a homozygote was confirmed by the results of three single alleles, for allelic dropouts are much more common than false alleles in noninvasive analysis (Gagneux et al. 1997; Baumgardt et al. 2013). Furthermore, the genotyping results could also be mutually confirmed by different DNA sources. For example, genotypes of plucked feathers or buccal swabs could be verified by blood samples from the same individuals, while genotypes of eggshell swab samples could be verified by comparing them with those of other sample types (blood, plucked feathers and buccal swabs), obtained from hatched nestlings in the same nest. Moreover, sample quality indices (SQI) and loci quality indices (LQI), ranging from 0 to 1 (described in Miquel et al. 2006), were calculated for each sample and locus to reflect clearly the reliability of microsatellite genotypes using the multipletube approach.

\section{Results \\ DNA concentration}

A total of 159 samples from six different types were collected in the field (Table 1). The DNA concentrations extracted from nondestructive samples including 31 plucked feathers ranging from 100.5 to $276.5 \mathrm{ng} /$ $\mu \mathrm{L}$ (Mean $\pm \mathrm{SE}=182.49 \pm 7.95$ ) and 13 buccal swabs ranging from 53.0 to $123.0 \mathrm{ng} / \mu \mathrm{L}(86.69 \pm 5.68)$. A significant difference was found in the mean values of both DNA concentrations (Independent $t$ test, $t=-9.804$, $\mathrm{df}=42, p<0.001$ ). DNA concentrations extracted from noninvasive samples included 64 eggshell swabs ranging from 7.0 to $58.0 \mathrm{ng} / \mu \mathrm{L}$ (Mean $\pm \mathrm{SE}=27.2 \pm 1.44$ ) and 16 shed feathers between 5.0 and $30.0 \mathrm{ng} / \mu \mathrm{L}(13.59 \pm 2.10)$.

Table 1 Number of DNA samples collected and successfully amplified with various primers

\begin{tabular}{llrrrr}
\hline Sample type & $\begin{array}{l}\text { Invasiveness } \\
\text { category }\end{array}$ & $\boldsymbol{N}_{\mathbf{a}}$ & $\mathbf{N}_{\mathbf{b}}$ & $\boldsymbol{N}_{\mathbf{c}}$ & $\boldsymbol{N}_{\mathbf{d}}$ \\
\hline Blood & Invasive & 16 & 16 & 16 & 16 \\
Plucked feathers & Nondestructive & 31 & 31 & 31 & 31 \\
Buccal swabs & Nondestructive & 13 & 13 & 13 & 13 \\
Eggshell swabs & Noninvasive & 64 & 64 & 62 & $55^{\text {a }}$ \\
Shed feathers & Noninvasive & 16 & 15 & 15 & 15 \\
Feces & Noninvasive & 19 & 13 & 11 & 11 \\
Total & & 159 & 152 & 148 & 141 \\
\hline
\end{tabular}

$N_{\mathrm{a}}$ number of samples collected in the field, $N_{\mathrm{b}}$ number of samples that successfully amplified mtDNA, $N_{c}$ number of samples successfully amplified with the CHD gene, $N_{d}$ number of samples that successfully amplified more than 5 microsatellite loci

a Five eggshell swabs with DNA contamination were also eliminated
Those extracted from fecal samples were the lowest, ranging from 1.25 to $27.5 \mathrm{ng} / \mu \mathrm{L}(9.77 \pm 1.83, n=19)$. The DNA concentrations of the three noninvasive samples differed significantly from each other (ANOVA: $F_{2}$, $\left.{ }_{96}=25.738, p<0.001\right)$, but shed feathers and feces did not (Independent t-test, $t=-1.376, \mathrm{df}=33, p=0.178$ ). All the same, DNA concentrations obtained from blood samples were the highest, ranging from 154.0 to $385.5 \mathrm{ng} /$ $\mu \mathrm{L}(252.16 \pm 17.05, n=16)$ (Table 2).

\section{Amplification success rate and microsatellite genotyping performances}

One DNA template obtained from shed feathers and six DNA samples extracted from feces were excluded from further analysis (Table 1), because they were not amplified by the partial ND6 and tRNA ${ }^{\text {Glu }}$ genes, although their DNA concentrations were not statistically lower than the successfully amplified fecal samples (Mann-Whitney U-test, $Z=-1.852, p=0.072$ ). All of the DNA samples extracted from blood, eggshell swabs, plucked feathers and buccal swabs were successfully amplified (Table 2). For the amplification of the CHD gene, two samples of both eggshell swabs and feces were not successfully amplified. All of the other noninvasive, nondestructive and invasive samples were amplified successfully (Table 2). As expected, eggshell swab samples, as verified by sex determination, were identified as female.

In the microsatellite marker polymorphism of 16 blood samples, the number of alleles per polymorphic locus ranged between 4 and 16, with observed heterozygosity ranging from 0.625 to 0.938 and expected heterozygosity from 0.673 to 0.954 (Table 3). A medium-to-high degree of polymorphism was detected per locus with PIC values ranging from 0.586 to 0.919 (Table 3). All of the loci conformed to the Hardy-Weinberg equilibrium, although two loci, Ae47 and Ae50, exhibited significant linkage disequilibrium. No significant null alleles, allele drop out or stuttering was found at any of the loci.

Among the 152 DNA samples that successfully amplified for mtDNA, 141 samples were successfully genotyped for at least five of the nine loci and were without contamination (Table 1). Four eggshell swabs and two fecal DNA samples were discarded as they amplified less than five loci. The eggshell swab and fecal samples that were not amplified by the CHD gene also had low success rates for microsatellite loci. No significant difference was found between the DNA concentration of the failed eggshell swabs and that of the amplified ones (MannWhitney U-test, $Z=0.549, p=0.924)$. Small amounts of fecal material inevitably had low DNA concentrations, while a significant difference in DNA concentration was found between the fecal DNA samples removed from final analysis and those retained (Mann-Whitney U-test, 
Table 2 Success rates of DNA concentrations and mitochondrial (mt)DNA and chromo-helicase-DNA-binding (CHD) gene amplification

\begin{tabular}{lll}
\hline Sample type & DNA concentration $(\mathbf{n g} / \boldsymbol{\mu L})$ & Successful PCR amplifications \\
\cline { 2 - 3 } & & Species identification \\
\hline Blood $(n=16)$ & $252.16 \pm 17.05$ & $16(100 \%)$ \\
Plucked feathers $(n=31)$ & $182.49 \pm 7.95$ & $31(100 \%)$ \\
Buccal swabs $(n=13)$ & $86.69 \pm 5.68$ & $13(100 \%)$ \\
Eggshell swabs $(n=64)$ & $27.20 \pm 1.44$ & $64(100 \%)$ \\
Shed feathers $(n=16)$ & $13.59 \pm 2.10$ & $15(93.75 \%)$ \\
Feces $(n=19)$ & $9.77 \pm 1.83$ & $13(68.42 \%)$ \\
\hline
\end{tabular}

Table 3 Characterization of nine polymorphic microsatellite loci

\begin{tabular}{|c|c|c|c|c|c|c|c|c|c|c|}
\hline Locus & Size range (bp) & Dye & $\begin{array}{l}\text { Annealing } \\
\text { temperature }\left({ }^{\circ} \mathrm{C}\right)\end{array}$ & $N_{\mathrm{A}}$ & $n$ & $H_{0}$ & $H_{\mathrm{e}}$ & PIC & HWE & \\
\hline \multicolumn{11}{|c|}{ Multiplex 1} \\
\hline Ae 36 & $94-114$ & HEX & 62 & 6 & 16 & 0.875 & 0.813 & 0.755 & 0.875 & NS \\
\hline Ae 01 & $143-159$ & TAMRA & 62 & 5 & 16 & 0.750 & 0.685 & 0.609 & 0.900 & NS \\
\hline Ae 47 & $171-195$ & FAM & 62 & 7 & 16 & 0.813 & 0.843 & 0.791 & 0.344 & NS \\
\hline \multicolumn{11}{|c|}{ Multiplex 2} \\
\hline Ae 44 & $110-122$ & HEX & 62 & 4 & 16 & 0.625 & 0.673 & 0.586 & 0.868 & NS \\
\hline Ae 37 & $165-201$ & TAMRA & 62 & 7 & 16 & 0.688 & 0.714 & 0.660 & 0.447 & NS \\
\hline Ae 50 & $211-259$ & FAM & 62 & 7 & 16 & 0.813 & 0.843 & 0.791 & 0.344 & NS \\
\hline \multicolumn{11}{|c|}{ Multiplex 3} \\
\hline Ae 05 & $165-181$ & TAMRA & 58 & 5 & 16 & 0.688 & 0.772 & 0.704 & 0.070 & NS \\
\hline Ae 51 & $110-142$ & HEX & 58 & 5 & 16 & 0.688 & 0.692 & 0.626 & 0.447 & NS \\
\hline Ae 52 & $233-403$ & FAM & 58 & 16 & 16 & 0.938 & 0.954 & 0.919 & 0.284 & NS \\
\hline
\end{tabular}

The range of allele sizes is given in base pairs (bp); optimal annealing temperature for amplification $\left({ }^{\circ} \mathrm{C}\right)$

$N_{\mathrm{A}}$ number of observed alleles, $n$ sample size, $H_{0}$ observed heterozygosity, $H_{\mathrm{e}}$ expected heterozygosity, $P I C$ polymorphism information content, $H W E$ Hardy-Weinberg equilibrium test, $N S$ nonsignificant

$Z=-3.071, p=0.001)$. Five cases of DNA contamination were found in eggshell swabs, given that there was a third allele for the microsatellite markers. In order to guarantee reliability, all loci data for these five contaminated samples were excluded from further analysis. Genotypes obtained from buccal swabs $(n=10)$ and plucked feathers $(n=5)$ should be consistent with those obtained from the blood of the same individual and in the same nest, at least one allele at each locus was shared between eggshell swabs and nestlings. Amplification success rates were recorded for each locus of all sample types. These results are shown in Table 4.

The consensus genotypes for each locus and each sample in the repetition experiment were confirmed. Blood samples and buccal swabs produced particularly reliable genotypes with no appearance of ADO or FA (Table 4). In plucked feathers, one ADO (rate $2.67 \%$ ) and one FA $(1.08 \%)$ were observed at one locus. In eggshell swabs, six loci were affected by ADO (rates 1.45-2.84\%) and one FA (3.03 \%) was detected at one locus. In shed feathers, seven loci were affected by ADO with rates ranging from $4.76 \%$ to $19.05 \%$, while FA was observed in five loci $(2.22-4.44 \%)$. The error rate was highest in the fecal samples, in which ADO (6.67-38.10\%) and FA (6.06$15.15 \%$ ) occurred in all nine loci (Table 4).

\section{Quality index for each sample and locus}

The results from measuring quality indices (QIs) were as expected from theoretical considerations. The buccal swabs $(n=13)$ sample quality index (SQI) was up to 1.0 (Fig. 2), as good as that of the blood samples. The SQI of the plucked feathers $(n=31)$ was 0.996 , that of eggshell swabs $(n=55) 0.986$ and of the shed feathers $(n=15)$ 0.918 . However, the SQI of feces $(n=11)$ was more variable, ranging from 0.55 to 1.0 (Fig. 2). The quality indices for locus (LQIs) of shed feathers and fecal samples were more variable than those of other sample types (Fig. 3). The average quality indices of nine loci for all samples 
Table 4 PCR success rate, frequency of allelic dropout (ADO) and false alleles (FA) for microsatellite genotyping

\begin{tabular}{|c|c|c|c|c|c|c|c|c|c|}
\hline & Ae36 & Ae01 & Ae47 & Ae44 & Ae37 & Ae50 & Ae05 & Ae51 & Ae52 \\
\hline \multicolumn{10}{|l|}{ Blood $(n=16)$} \\
\hline PCR number $(N)$ & 48 & 48 & 48 & 48 & 48 & 48 & 48 & 48 & 48 \\
\hline PCR success rate (\%) & 100 & 100 & 100 & 100 & 100 & 100 & 100 & 100 & 100 \\
\hline Heterozygotes $\left(H_{z}\right)$ & 42 & 36 & 39 & 30 & 33 & 39 & 33 & 33 & 45 \\
\hline ADO rate $(\%)$ & 0 & 0 & 0 & 0 & 0 & 0 & 0 & 0 & 0 \\
\hline FA rate $(\%)$ & 0 & 0 & 0 & 0 & 0 & 0 & 0 & 0 & 0 \\
\hline \multicolumn{10}{|c|}{ Plucked feathers $(n=31)$} \\
\hline PCR number $(N)$ & 93 & 93 & 94 & 93 & 93 & 93 & 93 & 93 & 93 \\
\hline PCR success rate (\%) & 100 & 100 & 98.94 & 100 & 100 & 100 & 100 & 100 & 100 \\
\hline Heterozygotes $\left(H_{z}\right)$ & 72 & 42 & 75 & 81 & 66 & 75 & 63 & 66 & 81 \\
\hline ADO rate (\%) & 0 & 0 & 2.67 & 0 & 0 & 0 & 0 & 0 & 0 \\
\hline FA rate (\%) & 0 & 0 & 0 & 0 & 0 & 1.08 & 0 & 0 & 0 \\
\hline \multicolumn{10}{|l|}{ Buccal swabs $(n=13)$} \\
\hline PCR number $(N)$ & 39 & 39 & 39 & 39 & 39 & 39 & 39 & 39 & 39 \\
\hline PCR success rate (\%) & 100 & 100 & 100 & 100 & 100 & 100 & 100 & 100 & 100 \\
\hline Heterozygotes $\left(H_{z}\right)$ & 33 & 30 & 27 & 30 & 36 & 27 & 30 & 15 & 36 \\
\hline ADO rate (\%) & 0 & 0 & 0 & 0 & 0 & 0 & 0 & 0 & 0 \\
\hline FA rate $(\%)$ & 0 & 0 & 0 & 0 & 0 & 0 & 0 & 0 & 0 \\
\hline \multicolumn{10}{|l|}{ Eggshell swabs $(n=55)$} \\
\hline PCR number $(N)$ & 165 & 167 & 166 & 165 & 166 & 166 & 165 & 166 & 167 \\
\hline PCR success rate (\%) & 100 & 98.80 & 99.40 & 100 & 99.40 & 99.40 & 100 & 99.40 & 98.80 \\
\hline Heterozygotes $\left(H_{z}\right)$ & 144 & 141 & 138 & 99 & 120 & 138 & 117 & 114 & 165 \\
\hline ADO rate (\%) & 0 & 2.84 & 1.45 & 0 & 1.67 & 1.45 & 0 & 1.75 & 2.42 \\
\hline FA rate $(\%)$ & 0 & 0 & 0 & 3.03 & 0 & 0 & 0 & 0 & 0 \\
\hline \multicolumn{10}{|l|}{ Shed feathers $(n=15)$} \\
\hline PCR number $(N)$ & 45 & 45 & 45 & 47 & 47 & 47 & 46 & 46 & 49 \\
\hline PCR success rate (\%) & 100 & 100 & 100 & 95.74 & 95.74 & 95.74 & 97.83 & 97.83 & 91.84 \\
\hline Heterozygotes $\left(H_{z}\right)$ & 42 & 33 & 42 & 42 & 42 & 42 & 33 & 30 & 42 \\
\hline ADO rate (\%) & 0 & 0 & 4.76 & 11.90 & 9.52 & 9.52 & 9.09 & 6.67 & 19.05 \\
\hline FA rate (\%) & 2.22 & 2.22 & 0 & 2.22 & 0 & 0 & 2.22 & 0 & 4.44 \\
\hline \multicolumn{10}{|l|}{ Feces $(n=11)$} \\
\hline PCR number $(N)$ & 35 & 34 & 35 & 35 & 35 & 35 & 36 & 35 & 35 \\
\hline PCR success rate (\%) & 94.29 & 97.06 & 94.29 & 94.29 & 94.29 & 94.29 & 91.67 & 94.29 & 94.29 \\
\hline Heterozygotes $\left(H_{z}\right)$ & 30 & 30 & 33 & 27 & 27 & 33 & 21 & 30 & 24 \\
\hline ADO rate (\%) & 13.33 & 6.67 & 12.12 & 14.81 & 14.81 & 12.12 & 38.10 & 16.67 & 29.17 \\
\hline FA rate (\%) & 9.09 & 15.15 & 6.06 & 9.09 & 6.06 & 12.12 & 6.06 & 9.09 & 9.09 \\
\hline
\end{tabular}

Based on three independent PCR replicates of each locus. DNA samples that failed to amplify mtDNA and succeeded in amplifying less than five loci were removed from the analysis. The variable $n$ indicates sample size and $N$ the number of PCR trials. $H_{z}$ represents heterozygote genotypes used for estimating error rates

were high (LQI > 0.9), except for feces which ranged from 0.70 to 0.82 .

\section{Discussion}

The quantity of genomic DNA from nondestructive and noninvasive sampling was sufficient for amplifications when common protocols were properly modified. In the present study, phenol-chloroform was used in the DNA extraction, an Axygen kit was used to remove PCR inhibitors and a $60 \mu \mathrm{L}$ elution buffer was added for DNA preservation. The plucked feathers and buccal swabs from the Chinese Egret yielded higher DNA concentrations than those from other species (see Bush et al. 2005; Yannic et al. 2011). Eggshell swabs yielded an average of $27.2 \mathrm{ng} / \mu \mathrm{L}(7.0-58.0 \mathrm{ng} / \mu \mathrm{L})$ genomic DNA, which was as good as other investigators obtained (Schmaltz et al. 2006; Martín-Gálvez et al. 2011). The shed feathers obtained DNA concentrations close to those of the red grouse $(15.73 \mathrm{ng} / \mu \mathrm{L})$ (Johansson et al. 2012), but much lower than those of the Spanish Imperial Eagle (Aquila 


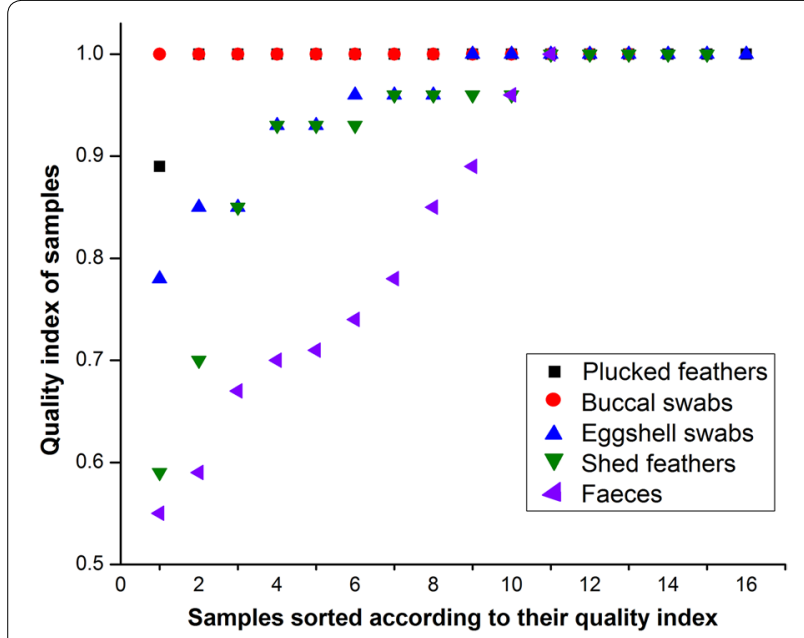

Fig. 2 Sample quality index (SQI) of different DNA sources. Indices for each sample type are sorted in ascending order. For plucked feathers and eggshell swabs, only the first 16 indices can be shown and those not shown are all equal to 1.0. The SQI of different sample types may overlap when they are equal to 1.0

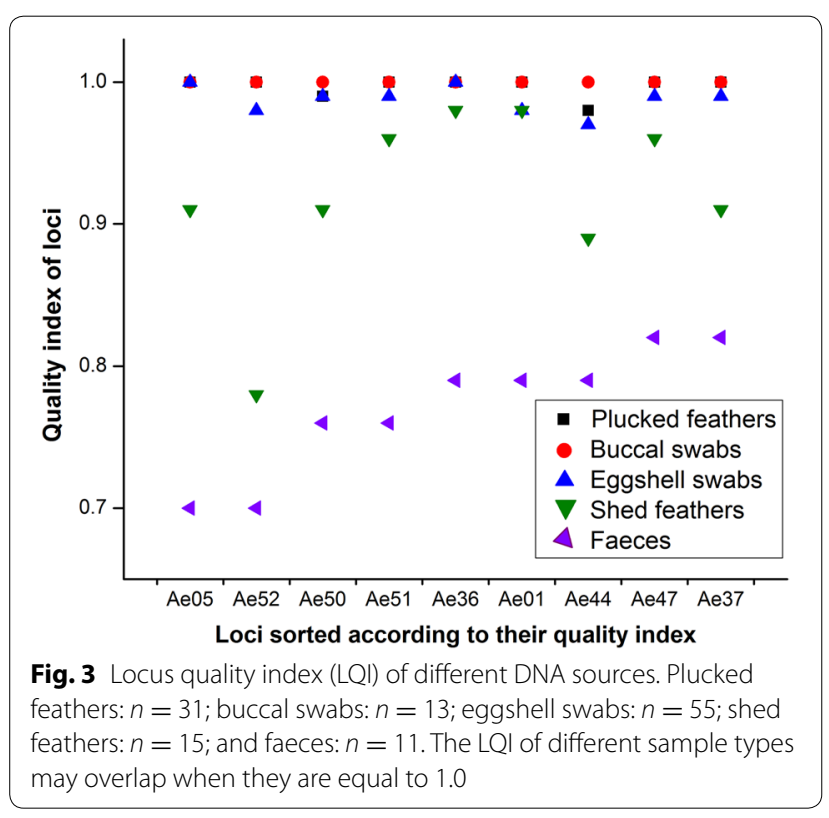

adalberti) (92.19 ng/ $\mu \mathrm{L})$ (Horvâth et al. 2005) and the

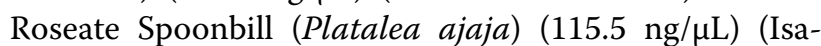
bel and Del Lama 2009). Feces yielded the lowest DNA concentrations among all samples and some of these were even less than $10 \mathrm{ng} / \mu \mathrm{L}$. PCR success in amplifying mtNDA and nDNA from noninvasive and nondestructive samples was good, although some of the noninvasive material did not perform well in PCR. In our study, we used equal amounts of DNA template $(\sim 50 \mathrm{ng})$ in each PCR, although DNA volumes varied considerably in different types of samples; for instance, to use a $50 \mathrm{ng}$ DNA template, a $0.4 \mu \mathrm{L}$ and DNA template was added from the plucked feather and $5 \mu \mathrm{L}$ from the fecal samples.

Genotyping errors were obtained and quality indices for each sample and locus calculated using the genetic material for which most microsatellites were amplified. Nondestructive samples, as with invasive material, exhibited high DNA quality and low genotyping error rates. The genotypes from nondestructive samples, (i.e., plucked feathers and buccal swabs) and blood samples were entirely consistent within individuals. The microsatellite genotyping performance of nondestructive samples was more reliable than that of noninvasive samples. Many previous studies have reported that genotyping errors can arise from low amounts of DNA, PCR inhibitors, DNA degradation or contamination of samples (Bush et al. 2005; Deagle et al. 2006; Renan et al. 2012). Of the noninvasive samples used in the present study, DNA extracted from eggshell swabs yielded the greatest amount and best quality, but some of the samples likely had DNA contamination caused by a male partner who shared the incubation with females (Skutch 1957; Matysioková and Remeš 2014). To minimize this contamination, eggshells should be swabbed as soon as the eggs are laid (Schmaltz et al. 2006). In the noninvasive shedfeather and fecal samples, ADO and FA might decrease the accuracy of microsatellite genotyping and affect the quality index for each sample and locus. For noninvasive fecal samples, the quality index of samples or loci might be the lowest of all of the different types of samples because of low levels of DNA material and quality. Noninvasive sampling, particularly fecal sampling, has many difficulties whether in the field or under laboratory conditions, where their quality largely depends on environmental conditions, sampling time, preservation methods, DNA extraction reagent, PCR system and its conditions. Therefore, further improvement of PCR success rates and decreasing genotyping errors for noninvasive material is necessary.

\section{Conclusions}

Overall, the present results indicate that both noninvasive and nondestructive samples can provide sufficient amounts of DNA material and quality for species identification, sex determination and microsatellite genotyping, with the exception of fecal DNA. All the same, we still present some advice on using the less invasive samples for studies in molecular ecology. First, collecting samples as fresh as possible in the wild will keep the DNA template from degrading or becoming contaminated. Second, DNA concentration evaluation of different sample types can help to control the amount of template in each PCR, while 
optimization of PCR systems and conditions can greatly increase the PCR success rate. Finally, evaluating PCR error rates by establishing their(?) criteria will help identify poor quality samples and loci. We anticipate that these microsatellite genotyping results will facilitate the application of noninvasive and nondestructive sampling methods for avian genetics studies.

\section{Authors' contributions}

YD designed and performed the experiments, completed the analyses, wrote and revised the manuscript; $X C$ and $X Z$ conceived, directed, and coordinated this study, helped with writing and revised the manuscript. QL and WZ collected the samples, assisted with analyses and lab work. All authors read and approved the final manuscript.

\section{Acknowledgements}

We thank Wei Lei, Site Luo, Leiguan Li and Changfu Mao who helped collect some samples for this study. This research was supported by the National Natural Science Foundation of China (Grant nos. 41476113, 31000963 and 31272333 ) and the Fujian Natural Science Foundation of China (2010Y2007).

\section{Competing interests}

The authors declare that they have no competing interests.

Received: 12 February 2015 Accepted: 22 November 2015

Published online: 04 December 2015

\section{References}

Baumgardt JA, Goldberg CS, Reese KP, Connelly JW, Musil DD, Garton EO, Waits LP. A method for estimating population sex ratio for sage-grouse using noninvasive genetic samples. Mol Ecol Resour. 2013;13:393-402.

BirdLife International. Species factsheet: Egretta eulophotes. 2014. [http://www. birdlife.org].

Bonin A, Bellemain E, Bronken Eidesen P, Pompanon F, Brochmann C, Taberlet $P$. How to track and assess genotyping errors in population genetics studies. Mol Ecol. 2004;13:3261-73.

Brooks R, Williamson J, Hensley A, Butler E, Touchton G, Smith E. Buccal cells as a source of DNA for comparative animal genomic analysis. Biotech Lett. 2003;25:451-4.

Broquet T, Petit E. Quantifying genotyping errors in noninvasive population genetics. Mol Ecol. 2004;13:3601-8.

Brown MB, Brown CR. Blood sampling reduces annual survival in cliff swallows (Petrochelidon pyrrhonota). Auk. 2009;126:853-61.

Bush KL, Vinsky MD, Aldridge CL, Paszkowski CA. A comparison of sample types varying in invasiveness for use in DNA sex determination in an endangered population of greater Sage-Grouse (Centrocercus uropihasianus). Conserv Genet. 2005;6:867-70.

Costantini V, Guaricci AC, Laricchiuta P, Rausa F, Lacalandra GM. DNA sexing in Humboldt Penguins (Spheniscus humboldti) from feather samples. Anim Reprod Sci. 2008;106:162-7.

Criscuolo F. Does blood sampling during incubation induce nest desertion in the female common eider Somateria mollissima. Mar Ornithol. 2001;29:47-50.

Dai Y, Zhou X, Fang W, Lin Q, Chen X. Development and cross-species transferability of 23 microsatellite markers from the vulnerable Chinese Egret (Egretta eulophotes) using 454 sequencing. Conserv Genet Resour. 2013;5:1035-8.

Deagle BE, Eveson JP, Jarman SN. Quantification of damage in DNA recovered from highly degraded samples - a case study on DNA in faeces. Front Zool. 2006;3:11.

Egloff C, Labrosse A, Hebert C, Crump D. A nondestructive method for obtaining maternal DNA from avian eggshells and its application to embryonic viability determination in herring gulls (Larus argentatus). Mol Ecol Resour. 2009;9:19-27.
Gagneux P, Boesch C, Woodruff DS. Microsatellite scoring errors associated with noninvasive genotyping based on nuclear DNA amplified from shed hair. Mol Ecol. 1997;6:861-8.

Gebhardt KJ, Waits LP. High error rates for avian molecular sex identification primer sets applied to molted feathers. J Field Ornithol. 2008;79:286-92.

Handel CM, Pajot LM, Talbot SL, Sage GK. Use of buccal swabs for sampling DNA from nestling and adult birds. Wildl Soc Bull. 2006;34:1094-100.

Horvâth MB, Martìnez CB, Negro JJ, Kalmâr L, Godoy JA. An overlooked DNA source for non-invasive genetic analysis in birds. J Avian Biol. 2005;36:84-8.

Huang X, Zhou X, Chen M, Fang W, Chen X. Isolation and characterization of microsatellite loci in vulnerable Chinese egret (Egretta eulophotes: Aves). Conserv Genet. 2010;11:1211-4.

Huang X, Zhou X, Lin Q, Peng Z, Fang W, Chen X. A novel multiplex PCR assay for species identification in the Chinese Egret (Egretta eulophotes) and Little Egret (E. garzetta). Conserv Genet Resour. 2012a;4:31-3.

Huang X, Zhou X, Lin Q, Fang W, Chen X. An efficient molecular sexing of the vulnerable Chinese egret (Egretta eulophotes) from faeces samples. Conserv Genet Resour. 2012b;4:391-3.

Huang X, Zhou X, Lin Q, Fang W, Chen X. PCR-RFLP technique for species identification of molted feathers in six species of co-occurring Ardeids. Conserv Genet Resour. 2013;5:817-9.

Idaghdour Y, Broderick D, Korrida A. Faeces as a source of DNA for molecular studies in a threatened population of great bustards. Conserv Genet. 2003:4:789-92.

Isabel MC, Del Lama Sn. Molted feathers as a source of DNA for genetic studies in waterbird populations. Waterbirds. 2009;32:322-9.

Johansson MP, Mcmahon BJ, Höglund J, Segelbacher G. Amplification success of multilocus genotypes from feathers found in the field compared with feathers obtained from shot birds. Ibis. 2012;154:15-20.

Kalinowski ST, Taper ML, Marshall TC. Revising how the computer program CERVUS accommodates genotyping error increases success in paternity assignment. Mol Ecol. 2007;16:1099-106.

Kang JH, Kim IK, Lee H, Rhim SJ. Distribution and Breeding Status of Chinese Egret Egretta eulophotes in South Korea. J Anim Vet Adv. 2013;12:618-20.

Litvinenko NM, Shibaev YV. Importance of Furugelm Island in the Sea of Japan for wetland birds: the first record of a breeding colony of the Chinese egret Egretta eulophotes. Oryx. 2000;34:335-7.

Martín-Gálvez D, Peralta SJ, Dawson D, Martín PA, Martínez BM, Burke T, Soler JJ. DNA sampling from eggshell swabbing is widely applicable in wild bird populations as demonstrated in 23 species. Mol Ecol Resour. 2011;11:481-93.

Matysioková B, Remeš $V$. The importance of having a partner: male help releases females from time limitation during incubation in birds. Front Zool. 2014;11:24.

Miquel C, Bellemain E, Poillot C, Bessiere J, Durand A, Taberlet P. Quality indexes to assess the reliability of genotypes in studies using noninvasive sampling and multiple-tube approach. Mol Ecol Notes. 2006;6:985-8.

Pompanon F, Bonin A, Bellemain E, Taberlet P. Genotyping errors: causes, consequences and solutions. Nat Rev Genet. 2005;6:846-7.

Regnaut S, Lucas FS, Fumagalli L. DNA degradation in avian faecal samples and feasibility of non-invasive genetic studies of threatened capercaillie populations. Conserv Genet. 2006;7:449-53.

Renan S, Speyer E, Shahar N, Gueta T, Templeton AR, Bar D. A factorial design experiment as a pilot study for noninvasive genetic sampling. Mol Ecol Resour. 2012;12:1040-7.

Rousset F. GENEPOP'007: a complete re-implementation of the genepop software for Windows and Linux. Mol Ecol Resour. 2008;8:103-6.

Sacchi P, Soglia D, Maione S, Meneguz G, Campora M, Rasero R. A non-invasive test for sex identification in Short-toed Eagle (Circaetus gallicus). Mol Cell Probe. 2004;18:193-6.

Schmaltz G, Somers CM, Sharma P, Quinn JS. Non-destructive sampling of maternal DNA from the external shell of bird eggs. Conserv Genet. 2006;7:543-9.

Shen Z, Qu W, Wang W, Lu Y, Wu Y, Li Z, Zhang C. MPprimer: a program for reliable multiplex PCR primer design. BMC Bioinformatics. 2010;11:143.

Skutch AF. The incubation patterns of birds. Ibis. 1957;99:69-93.

Taberlet P, Bouvet J. A single plucked feather as a source of DNA for bird genetic studies. Auk. 1991;108:959-60. 
Taberlet P, Griffin S, Goossens B, Questiau S, Manceau V, Escaravage N, Bouvet J. Reliable genotyping of samples with very low DNA quantities using PCR. Nucleic Acids Res. 1996;24:3189-94.

Taberlet P, Waits LP, Luikart G. Noninvasive genetic sampling: look before you leap. Trends Ecol Evol. 1999;14:323-7.

Van Oosterhout C, Hutchinson WF, Wills DP, Shipley P. MICRO-CHECKER: software for identifying and correcting genotyping errors in microsatellite data. Mol Ecol Notes. 2004;4:535-8.

Wang Z, Zhou X, Lin Q, Fang W, Chen X. New primers for sex identification in the Chinese Egret and other ardeid species. Mol Ecol Resour. 2011;11:176-9.

Wang Z, Zhou X, Lin Q, Fang W, Chen X. Characterization, polymorphism and selection of major histocompatibility complex (MHC) DAB genes in vulnerable Chinese egret (Egretta eulophotes). PLoS One. 2013;8:e74185.
Wellbrock AH, Bauch C, Rozman J, Witte K. Buccal swabs as a reliable source of DNA for sexing young and adult Common Swifts (Apus apus). J Ornithol. 2012;153:991-4.

Yannic G, Sermier R, Aebischer A, Gavrilo MV, Gilg O, Miljeteig C, Broquet T. Description of microsatellite markers and genotyping performances using feathers and buccal swabs for the ivory gull (Pagophila eburnea). Mol Ecol Resour. 2011;11:877-89.

Zhou X, Wang Y, Chen X, Lin Q, Fang W, Wei D. A set of primer pairs for amplifying the complete mitochondrial DNA of endangered Chinese egret (Aves, Ardeidae, Egretta eulophotes). Mol Ecol Resour. 2008;8:412-4.

Zhou X, Fang W, Chen X. Mitochondrial DNA diversity of the vulnerable Chinese Egret (Egretta eulophotes) from China. J Ornithol. 2010;151:409-14.

Zhou X, Lin Q, Fang W, Chen X. The complete mitochondrial genomes of sixteen ardeid birds revealing the evolutionary process of the gene rearrangements. BMC Genom. 2014;15:573.

\section{Submit your next manuscript to BioMed Central and we will help you at every step:}

- We accept pre-submission inquiries

- Our selector tool helps you to find the most relevant journal

- We provide round the clock customer support

- Convenient online submission

- Thorough peer review

- Inclusion in PubMed and all major indexing services

- Maximum visibility for your research

Submit your manuscript at www.biomedcentral.com/submit

O) Biomed Central 